\title{
The Development of Hypothetical Learning Trajectory (HLT) Based on Problem Based Learning Topic Class VII SMP/ MTS
}

\author{
$1^{\text {st }}$ Stefina Maximovna \\ Mathematics and Science Faculty \\ Universitas Negeri Padang \\ Padang, Indonesia \\ stefinamaximovna@gmail.com
}

\author{
$2^{\text {nd }}$ Armiati \\ Mathematics and Science Faculty \\ Universitas Negeri Padang \\ Padang, Indonesia \\ armiati@fmipa.unp.ac.id
}

\begin{abstract}
The aim of this study is to produce a valid, practical and effective PBL-based learning tool to improve the solving mathematical problem ability of seventh-grade students of SMP/MTs. The learning tools developed are teacher books and student books. This research is a development research using Plomp model which consists of three stages of research; introduction, development, and assessment stage. In the development stage, the design and assessment of learning devices are carried out through the stages of formative evaluation. The field test subjects involved in this study were class VII students of ,MTsS PPM Subulussalam. The instruments used were teacher book validation sheets, student books, teacher response questionnaires, and student questionnaire responses. Before the instrument used to collect data, the instrument was first validated by the validator. The results of the analysis of the teacher book validation sheets and student books show that the learning tools developed were valid.
\end{abstract}

\section{INTRODUCTION}

Mathematics is a means of scientific thinking that can accelerate the development of exact sciences, engineering, social and other sciences. As stated by James and James in Suherman [1]. Mathematics is a means of thinking, it is logic in adulthood, it is the queen of science and at the same times its servant. Mathematics is the science of quantity and quantity, it is purely formal science, it is the science that manipulates symbols, and it is the study of the relationship of patterns, shapes, and structures.

The aim of Mathematics learning as stated in Permendikbud [2] is essentially related to cognitive, psychomotor and affective aspects. Objectives related to cognitive aspects are students able to understand mathematical concepts, use patterns as initial guesses, use reasoning, communicate ideas and be able to compile mathematical evidence by using complete sentences and symbols in problem solving, both in mathematics and outside mathematics. Freudenthal in Gravemeijer \& Eerde [3] argues that students should be given the opportunity to develop and develop their thinking skills when constructing mathematics. The objectives related to psychomotor aspects are that students are able to perform motoric activities related to mathematics, use teaching aids and technology in mathematical activities. The objectives related to the affective aspects are students will have an attitude of respecting the usefulness of mathematics and showing an attitude that is in accordance with its values.
Numbers are one of the mathematics materials learned in seventh grade junior high school. Number material studied is integers and fractions. Integers and fractions play an important role in mathematics because they are basic material that must be mastered by students before learning other material. Walle [4] explained that junior high school students need to develop a more complete understanding of the number system. This means they are expected to be able to understand more deeply about integers and fractions. The aim is so that they are able to face the next material.

Number material is material that is very difficult for most students to learn meaningfully because numbers are mathematical objects that cannot be represented physically. In mastering the concept of numbers, until now students still experience difficulties, especially in number material in junior high school. Kouba and his colleagues found that in the fourth National Assessment of Educational Progress (NAEP), most seventh grade students used fractional symbols without understanding. This is indicated by about $80 \%$ of seventh grade students being able to convert mixed fractions into imperfect fractions, but few of them know that the concept of $51 / 4$ is equal to $5+1 / 4$. This condition shows that the number material is understood by students as a meaningless symbol.

Other problems regarding numbers were also found during observations in several Enam Lingkung District junior high schools. The problem regarding teaching integers still tends to use absurd objects that only focus on algorithms. Students are taught material without being told the benefits of learning it in their daily lives. The student is given an algorithm to complete an integer operation then memorizes it without knowing the meaning. This results in less meaningful learning so that their mathematical problemsolving abilities are low.

Problem-based learning (PBL) is one of the lessons that can accommodate students in learning and improve problem solving skills in their daily lives. PBL invites students to solve problems around them. Students find concepts by solving problems and end by presenting and analyzing student work. In accordance with the opinion of Wena [5], "problem-based learning strategies are learning strategies by prioritizing students on practical problems as a foundation in learning or in other words students learn through problems". According to Sutirman [6], "problem-based learning is a learning model that departs from students' understanding of a 
problem, then selects the right solution to be used in solving the problem".

PBL not only helps students to understand concepts, but they also understand the application of subject matter into everyday problems. PBL students think to solve problems, find ideas and make decisions. Students will understand better because they are actively involved in building new knowledge, so they will remember more about all concepts and principles.

The role of the teacher can be maximized in the learning process so that the learning atmosphere becomes effective and on target. For that learning needs to be designed well. Learning that is not well designed means that the lessons received by students become less meaningful. Learning is only a condition of conveying the material, without knowing the meaning and purpose of the material being taught. For that reason, learning must be able to make students have curiosity so that they can understand the concept well and can build their own knowledge and can also solve problems with the right process and not only oriented towards the final result.

Learning design based on learning flow (learning trajectory) is known as Hypothetical Learning Trajectory (HTL). HTL is a learning flow that consists of learning, learning activities, and learning process hypotheses to predict how students' thoughts and understanding will develop in the context of Simon's learning activities [7]. An HLT can be based on one type of source such as conjecture without empirical data, experiment or teaching experience, pretest and posttest, written interview or protocol of several questions, structured task analysis, and so on, Chuang-Yih Chen [8].HTL also contains specific objectives of learning activities which are then complemented by activities to achieve each of the objectives that have been formulated previously.

In each activity that was designed, several hypotheses were made about what students were doing. Nurdin [9] stated that in designing learning activities, the learning path plan contains allegations that are expected to get responses from students for each stage in the learning trajectory. For students' activities that are not appropriate, there will be anticipations that direct students to the expected goals. This design can be done in a design study. Design research is made in three stages, the preparation, trial, and retrospective stages. In the preparation stage, a PBL-based learning design is designed. Each activity is complemented by the alleged flow of students' thinking that will develop along with anticipation.

\section{RESEARCH METHOD}

This research is a development research. The research model used is the Plomp development model. Plomp [10] provides a development model consisting of three phases, preliminary research, development or prototyping phase, and assessment phase. At the preliminary research, there are several activities carried out, collecting data, analyzing and identifying problems that occur in learning as the basis for determining alternative solutions and product specifications needed, studying the scope of the material needed to achieve indicators of competencies achievement. Analysis of this phase consists of needs analysis, curriculum analysis, concept analysis, and student analysis.
In the prototyping phase, the prototype was made the formative evaluation. The prototyping phase consists of prototype 1, namely self-evaluation and expert review. Self evaluation is the activity of evaluating teacher books, student books and HLT that have been designed with the help of colleagues. After being repaired, it is believed to be good and in accordance with expectations, then the assessment phase is carried out on the content validity by experts (expert review). The expert review activity will be conducted by five experts called validators consisting of three mathematicians, one education technology expert and one Indonesian language expert.

Prototype 2 is the evaluation results one by one. One-onone evaluation involves three seventh grade students with different learning abilities (high, medium, low). Prototype 3 is a small group evaluation. Small group evaluations will be conducted in class seven which consists of six people with different learning abilities (high, medium, low) and Prototype 4 is the result of a formative evaluation. During the assessment phase, a field test was carried out in the seventh grade of the Subulussalam PPM MTsS to see practicality and effectiveness. Research data was collected through validation sheets, teacher and students response questionnaire sheets and student learning test results.

\section{RESULT AND DISCUSSION}

\section{Preliminary Research}

At this stage identification or analysis is needed to develop the learning flow based on Problem Based Learning (PBL) and analyze the number material to be developed. The purpose of this stage is to establish and identify the conditions needed in developing the learning path. In this phase several activities were carried out including needs analysis, curriculum analysis, concept analysis and student analysis.

The preliminary analysis stage is done by interviewing and observing mathematics learning. The results of interviews and observations indicate the needs of students in the form of new learning models in addition to conventional learning commonly used in schools that are better able to optimize students' mathematical problem solving skills. In addition, existing teacher books and student books need to be refined to fit the demands of the 2013 curriculum and they can help teachers and students in learning and learning outcomes of students can be obtained maximally. In addition, student books also need to be equipped with problems and activities of students in solving the problem, so that it can help students understand the material they are learning. Student books also need to be filled with questions in the form of story questions so that students can practice developing their mathematical problem-solving abilities. Based on curriculum analysis, it is known that there are four materials in semester I, they are numbers, sets, algebra, and linear equations of one variable. The material taken for the development of the device in this study is number material.

In the concept analysis stage, activities are carried out to identify, detail, and systematically compile the main materials that students will learn. From the results of concept analysis, number material is taken as a learning tool for mathematics developed. As for the main concept in semester I in matter numbers are integers and fractional arithmetic operations involving integers and fractions. 
Based on the analysis of students it can be concluded that the mathematical learning carried out is less fun, students are less participating in learning mathematics. In addition, students stated that there was a need for student books that became learning resources to better understand learning material. Students want a book with an attractive appearance where the problem is in accordance with what is experienced everyday.

\section{Result of Prototyping Phase}

The purpose of this development is to produce a class VII mathematics / junior high school mathematics learning device based on Problem Based Learning to improve students' ability in solving valid, practical and effective problems. After the learning indicator is formulated, as well as the main concepts are determined through needs analysis, curriculum analysis, concept analysis and analysis of students that are carried out in the preliminary stage, then learning tools can be designed as needed.

\section{a. Designing learning tools}

Designing mathematics learning devices based on problem based learning is based on analysis in the initial investigation phase. The results of this design will produce a prototype 1 . The designed learning device refers to the characteristics of guided discovery based learning models. The following is a description of PBL learning-based learning tools.

1) Teacher's Book Characteristics

Teacher books are prepared based on Basic Competencies which consist of several indicators. The teacher's book is designed as a guide for teachers in delivering learning material. The designed teacher book contains the flow of learning, along with predictions and anticipation of students' answers. Learning activities presented in the teacher's book refer to problem based learning based on integrated learning in student books based on problem based learning In the Introduction activity, learning begins with giving motivation and focusing the attention of students to actively participate in the learning process. The method used by the teacher is orientation, apperception, motivation, and reference.

The next activity carried out in the learning process is the core activity. The core activity is a learning process to achieve learning goals. At the core activities, the teacher first introduces the problem based learning, then students are faced with several problems related to the material being studied. Then from this problem students discuss with their friends.

Next, the teacher asks students to discuss in groups. Students discuss all information contained in the problem given by writing down information that is known from verbal statements correctly and writing questions that represent problems in order to understand the problem properly. Next, the teacher asks one group to present the results of the group discussion in front of the class and the other group responds to the explanation from the presentation group. After group discussion students are asked to work on the given exercise questions to see the students' understanding of the material that has been learned.
The last activity carried out was closing activity. In the closing activity, students summarize or summarize the material that has been taught with the guidance of the teacher, and the teacher informs the material to be learned at the next meeting.

2) Student's Book Characteristic

Characteristics of Student's Book are divided on some aspects, is as follows:

a) Content Aspects

The presentation of the material begins by giving problems in everyday life related to the material being studied. Students are asked to solve problems given based on their knowledge and questions that must be answered by students so that students can solve the problem given.

Student Books contain daily problems that guide students to solve problems given. Students can answer in the space provided. In answering questions, students can discuss with friends in groups so that students can equate their ideas in answering the questions given. This can make students actively involved in solving these problems. In solving a given problem, students must first understand the problem given by various questions.

In the next section, students are given assignments that aim to see the level of understanding of students about the concepts they learn. Through practice, students are expected to gain learning experience and understand the material being studied. Students, who have found their own understanding and have been given emphasis by the teacher, are tested for understanding through practice questions in the student book based on this problem based learning. By doing this exercise, it is hoped that students can improve their understanding of the concepts or principles that have been learned and as proof that they know and understand the material. The number of questions for each material varies.

b) Language Aspect

This book uses standard language in accordance with Indonesian spelling (EBI). Student Book use simple and communicative language and in accordance with the level of understanding of junior high school / MTs students so that the presentation of material in the student book can be understood by students well. Problems in student books are arranged in clear sentences so that they are able to direct students to get the expected answers.

\section{c) Presentation Aspect}

This aspect focuses on the cover design, the type of font used, the layout, the suitability of the text and image sizes, and the parts that require emphasis. The cover page contains the student's identity or book title based on problem based learning, the subject title being studied. Student books are designed in blue, because the use of blue is to give a natural and fresh impression.

Based on the questionnaire about the characteristics of the student's book that students want, the main background color used in the student's book based on problem based learning is blue. The blue color also has a lot of positive influence on reader psychology.

\section{b. Self Evaluation}

The design of learning devices that have been completed is then examined by the researcher by using a self evaluation sheet. In general, many errors occur in typing words and punctuation. Errors in punctuation, for example, 
after punctuation is not spaced 1 space, lack punctuation marks such as periods and commas, letters are not capital after a period. In addition, there is also a table cut off with the next page so that the title is not visible. In student books typing errors, letter deficiencies, text size accuracy, less punctuation.

After self evaluation, a revision of the learning device was carried out. This revision result is called prototype 2 . Then the results of the prototype I are consulted or discussed with competent and validated experts. The results of the teacher book validation show that the value of each aspect is very valid. Overall, the developed teacher's book is said to be very valid with $92.99 \%$. So it can be concluded that the teacher's book based on problem based learning is very valid. In the book validation results, students showed that for the content aspect, the average validity was $92.1 \%$ with very valid categories, $100 \%$ language aspects with very valid categories, and $75 \%$ graphic aspects with valid categories. In general, student book validity is $88.57 \%$ with a valid category.

\section{c. Individual Evaluation Results}

At this one to one stage, the developed student book was tested on 3 students of class VII MTsS PPM Subulussalam with high, medium and low abilities. Student books Based on this problem based learning is given to students to be filled in according to their abilities, after the students are asked to comment on the students' books given. Student books are given to students outside of learning hours with different days. This evaluation was carried out on 8 activities on student books. These books are given to students to work on their activities. Researchers pay attention to what is done by students and record things or obstacles during work on the observation sheet. The questions asked were dominated by students with moderate abilities and low abilities. Based on the questions of students, researchers provide direction that guides students to build their knowledge. Through the direction given, students can understand and easily do activities on student books well.

Regarding the details of one-to-one evaluation, in general, revisions are limited to improvements to sentences. Improvements are made with the aim of getting a better problem based learning based learning device. The results of improvements in evaluation one-on-one are called prototypes 3 .

\section{d. Small group evaluation results}

In the small group evaluation, PBL-based student books that have been tested in one-on-one evaluation and have been revised were then trialed to small groups consisting of 6 students of class VII MTsS of Subulussalam PPM who have high, medium and low abilities.

Based on observations, there are several revisions of the learning tool: in terms of time, students need a long time to do the exercises contained in the student book based on a problem-solving approach.

\section{e. Field Test Phase Analysis}

The results of the revisions at each meeting on one-onone and small-group evaluations were followed by a field test (field test) at class VII.1 MTsS of Subulussalam PPM.
This trial was conducted to see the practicality and effectiveness of the learning tools that have been designed.

\section{Implementation Assessment}

a. Practicality Test

The practicality test of PBL-based student books aims to find out the extent of the benefits, ease of use and efficiency in the use of student books and PBL-based teacher books by teachers and students. Seeing the practicality of PBL-based student books, the trial was conducted 8 times, namely the number material. Practicality data is obtained from observations of the implementation of learning and the results of practicality questionnaires by teachers and students. The results of the practicality test for PBL-based student books are described as follows.

\section{b. Questionnaire on Teacher and Student Response}

Based on the results of the teacher response questionnaire, it can be seen that the average practical results of PBL-based books range from $84.72 \%$ to $90.73 \%$ with very practical criteria, with practical criteria to very practical. While the results of the student response questionnaire showed that the average results of the practicality test on student-based problem based learning books from $87.5 \%$ to $100 \%$ with very practical criteria. Thus, it can be concluded that teachers and students perceive PBL-based student books to be very practical to be used in mathematics learning in class VII of SMP /MTs.

In assessing the practicality of this device, data is collected through observation of the implementation of learning, a practical questionnaire filled by students and teachers. The implementation of learning using PBL learning tools shows that the learning process can create a good classroom situation that encourages students to ask questions, answer and express opinions and there is interaction between students. In addition, learning using devices based on problem solving approaches can stimulate students very well in improving students' motivation in learning and can develop independence and creativity in understanding student books and solving problems.

Based on the explanation above, the learning tool, in this case the teacher's book and PBL-based student book, is practical for students of class VII SMP / MTs. In the learning process, the teacher does not experience significant difficulties in using the teacher's book. Student books used by students can help them understand a concept of subject matter. In terms of time, the teacher's book and student books are used enough to complete the learning activities.

\section{c. Students' Problem Solving Ability Test (Effectiveness Test)}

The effectiveness of mathematics learning devices can be seen from the test results of students' mathematical problem solving skills. PBL-based learning devices can be said to be effective if they are able to increase students' mathematical problem solving skills. Learning outcomes obtained in this study came from tests given in the form of a description test consisting of two items. This test is done to assess the cognitive abilities of students after learning by using student books based on problem based learning. This test is given to students of class VII1 with 30 students. The results of the problem solving ability test are 24 students or 
$88.89 \%$ complete, which means that the value of students above the specified KKM value and 6 students or at $11.11 \%$ is incomplete, meaning that the value of students is still below the KKM. Furthermore, from the class average, learning using problem based learning based learning tools is 82.92, which means that classically it has shown completeness. From the results of this final test, it is known that more than $75 \%$ of students are above the KKM.

\section{CONCLUSION AND SUGGESTION}

This research is a development research that produces teaching materials based on problem based learning. The device is in the form of teacher's books and student books for numeric material in class VII. Based on the results of the study, the following conclusions were obtained: (1) The development of problem based learning teaching materials in the form of teacher books and student books was carried out with the Plomp development model consisting of three stages: preliminary research stage, development stage and assessment stage. (2) Learning based problem based learning materials that have been produced from this research have met the criteria of valid, practical and effective product quality.

Researchers suggest several things based on the conclusions and limitations of this study; (1) The teacher's book and the student's book based on problem based learning for Numbers VII grade material for the odd semester / junior high school that was developed has been declared valid, practical, and effective so it is recommended to be used by mathematics teachers as an alternative in learning. (2) For other researchers who will continue this research, it is recommended to innovate in subsequent research such as developing teacher books and student books in learning mathematics for other materials or new mathematics learning device innovations.

\section{REFERENCES}

[1] Suherman. Herman, Common Text Book Strategi Pembelajaran Matematika Kontenporer Bandung:JICA-Universitas, Pendidikan Indonesia (UPI), 2004

[2] Peraturan Menteri Pendidikan Nasional Nomor 22 Tahun 2006 tentang standar isi,Jakarta : Kemendikbud, 2006

[3] Gravemeijer. Koeno., Cobb. Paul, Design research from the Learning Design Perspective, Dalam Jan Ven Den Akker, et. al. Educational Design Research. London: Routledge, 2006.

[4] Walle. Van De, Matematika Sekolah Dasar dan Menengah Jilid 2 Pengembangan dan Pengajaran, Terjemahan dari oleh Suyono, Jakarta: Erlangga, 2006.

[5] Wena. Made, Strategi Pembelajaran Inovatif kontemporer, Jakarta: Bumi Aksara, 2011.

[6] Sutirman, Model-model Pembelajaran Inovatif. Yogyakarta: Graha Ilmu, 2013.

[7] Simon. Martin A,Reconstructing mathematics pedagogy from a construktivist perspective. Journal of research in mathematics education, Volume26, no.2135-137,1995. (http://jwilson.coe.uga.edu/EMAT7050/Students/Gainey/Article\%20.pd f)
[8] Chuang-Yin Chen, A Hypotetical Learning Trajectory of Arguing Statements about Geometric Figures, 2002.(http://www.math.ntnuEdu.tw)

[9] Nurdin. 2011. Trajektori Dalam Pembelajaran Matematika. (Online), Vol. 01 No.01, http://download.portalgaruda.org/article.php?article=11834\&val=870,

[10] Plomp. Tjeerd., Nieveen. Nienke, Educational Design Research, Part A. An Introduction, SLO,Netherlands Institute for Curriculum Development, 2013. 